Yun-fang Dai*

\title{
"I should like to have my name talked of in China": Charles Lamb, China, and Shakespeare
}

\begin{abstract}
Charles and Mary Lamb’s Tales from Shakespeare played an essential role in Chinese reception history of Shakespeare. The first two adaptations in China, Xiewai qitan 澥外奇譚 and Yinbian yanyu 吟邊燕語, chose Tales as the source text. To figure out why the Lambs' Tales was received in China even earlier than Shakespeare's original texts, this paper first focuses on Lamb's relationship with China. Based on archival materials, it then assumes that the Lambs' Tales might have had a chance to reach China at the beginning of the nineteenth century through Thomas Manning. Finally, it argues that the decision to first bring Shakespeare to China by Tales was made under the consideration of the Lambs' writing style, the genre choice, the similarity of the Lambs' and Chinese audiences, and the marketability of Tales. Tracing back to the first encounter between Tales and China throws considerable light on the reception history of Shakespeare in China. It makes sense that nothing is coincidental in the history of cultural reception and the encounters have always been fundamentally influenced by efforts from both the addresser and the receptor.
\end{abstract}

Keywords: Shakespeare; tales; Charles Lamb; Yinbian yanyu; Thomas Manning.

In 1806 Charles Lamb wrote a letter to Thomas Manning, expressing "I should like to have my name talked of in China" (Radcliffe 349). ${ }^{1}$ His wish is finally realized through the publication of Tales from Shakespeare (1807), a collaborative work with his sister Mary Lamb, and its subsequent translation into Chinese. ${ }^{2}$ The success of this work was so huge that when discussing Shakespeare's initial reception in China, the first name that comes to mind, rather than the translations by Liang Shiqiu 梁實秋 or Zhu Shenghao 朱生豪, is Yinbian Yanyu 吟邊燕語,

\footnotetext{
Associate Professor, School of Foreign Studies, Nantong University, China.

1 The letter was sent on May $10^{\text {th }} 1806$.

2 The paragraph involving this sentence was added into David Hill Radcliffe's new edition of The Works of Charles and Mary Lamb online, which is noticeably different from E. V. Lucas’ old edition in 1905 and Percy Fitzgerald's edition in 1971.
} 
a collaborative translation by Lin Shu 林紓 and Wei Yi 魏易, based on the Lambs' Tales. ${ }^{3}$ This naturally leads to the questions of why the Lambs' Tales came into China even earlier than Shakespeare's own works and why it exerted a much greater influence than the translations of the original works in promoting the Bard's fame in China at the turn of the twentieth century.

In response to these questions, I will trace back to the beginning point of the journey, where Charles Lamb, rather than a remote author of the source text, was more relegated to the target culture. This essay aims to re-evaluate the relationship between Lamb and China through investigating Tales, his letters, and essays. It will focus on Lamb's conception of China, an ancient and exotic oriental country, in order to illustrate the link between Tales and its influence on China.

\section{"The farthest ends of the world": China, the Stealer and the Other}

As Peter J. Kitson points out, "Recent Lamb criticism has rightly shifted the focus of enquiry from the biographical and metropolitan to the global networks of the periodical culture in which Lamb's work is situated" (170). In this extensive landscape of the networks, China undoubtedly occupies a position. When tracing the connection between Lamb and China, Thomas Manning is one that cannot be ignored. Manning, a Sinologist and also "the first Englishman to enter Lhasa and receive an audience with the ninth Dalai Lama in 1811," is "regarded by many as the preeminent expert on China in the Romantic period" (Kitson 174). Manning grew interested in the Chinese language when he was studying at Cambridge, where he met Lamb and they became each other's good friend. ${ }^{4}$ He later studied Mandarin in Paris for three years, after which he followed a native Chinese speaker to London. In order to master the Chinese language, Manning planned to venture to China.

However, the decision is met with strong resistance from Lamb. He writes to William Hazlitt, their mutual friend, talking about Manning's plan to China: "Manning is not gone to China, but talks of going this Spring. God forbid" (Fitzgerald 258). In an attempt to persuade his friend from adventuring out to China, Lamb begins to describe this remote country in his letters to Manning. The following is an extract from one of the letters:

3 The name of Yinbian yanyu is the shorthand of its original full title Yingguo shiren yinbian yanyu (“An English Poet Reciting from Afar” rendered by Alexa Huang/ "Familiar Stories Recited from Afar" rendered by César Guarde-Paz). Romanization of Chinese names and words follow the Hanyu Pinyin system, except in cases where a proper name or common usage is in another system.

4 The year that they met was 1799, when Lamb was at his twenty-four and Manning was two years older. 
I heard that you were going to China, with a commission from the Wedgwoods to collect hints for their pottery, and to teach the Chinese perspective; but I did not know that London lay in your way to Pekin. I am seriously glad of it, for I shall trouble you with a small present for the Emperor of Usbeck Tartary, as you go by his territories: it is a fragment of a "Dissertation on the state of political parties in England at the end of the eighteenth century," which will no doubt be very interesting to his Imperial Majesty. (Fitzgerald 202)

Several details about China in this letter are worth discussing. Kitson, for example, argues that "to collect hints for their pottery" and "to teach Chinese perspective" are twin concerns of his two China essays, "Old China" and "Dissertation upon Roast Pig” (173). However, my attention is drawn to Lamb’s mentioning of "Tartary," which was closely associated with the image of China in Western literary works during the seventeenth and eighteenth centuries.

Among these works, Voltaire's L'Orphelin de la Chine may have been relevant to Lamb. The book depicts the resistance of a gentle and civilized Chinese woman against a militaristic and barbaric Tartar man. Voltaire's story is based on Joseph de Prémare's translation of the Chinese story, Zhaoshi Gu'er 趙氏孤兒 [The Orphan of Zhao], first written when China fell to the Tartars in the thirteenth century. ${ }^{5}$ The war was led by Genghis-Khan, who might be the base figure of the Tartary Emperor earlier mentioned by Lamb. ${ }^{6}$ The following extract from Lamb's letter to William Wordsworth in 1814 offers a piece of evidence that Lamb reads Voltaire.

That Objection which M. Burney had imbibed from him about Voltaire I explained to M.B. (or tried) exactly on your principle of its being a characteristic speech. That it was no settled comparative estimate of Voltaire with any of his own tribe of buffoons-no injustice, even if you spoke it, for I dared say you never could relish Candide. (Fitzgerald 92-93)

Lamb expresses his negative feeling about Voltaire. The situation is made even more complicated by the relationship between Voltaire and China, as Lamb's thoughts on Voltaire might reflect his attitude towards China. Voltaire is famous for his appreciation of Chinese culture, particularly of Confucius. As Rosalind Ballaster points out, "according to Voltaire, the French encounter and identification with Chinese values may enable progress from a state of primitive submission to the authority of Church and State, of primitive submission to

5 For more discussions on Prémare's translation, see Tu Hsin-hsin, "Literature, Translation, and the Critics: On Prémare's Translation of Le Petit Or-phelin de la Maison de Tchao.”

${ }^{6}$ Genghis-Khan is also the base figure for Elkanah Settle's The Conquest of China, by the Tartars, a story about a Chinese princess and a Tartary prince. 
Enlightenment values of curiosity and openness" (214). Voltaire is fascinated with Chinese culture and values, which might inspire his Enlightenment ideas. When involving China into consideration, it is easy to build a link between Lamb's hatred to Voltaire and Voltaire's enthusiasm of China. However, the reason for Lamb's negative thoughts to Voltaire can be attributed to sophisticated reasons. We cannot rashly deduce Lamb's views on China from such a slight clue. Conversely, Lamb's feeling towards China is far more confusing than simple hatred or disgust. The image of China presented and instituted in Lamb's words explains what China is perceived in his mind.

The first point worth mentioning is that Lamb expresses curiosity about China. For example, in one of his letters to Manning he mentions China's Great Wall: "How the paper grows less and less! In less than two minutes I shall cease to talk to you, and you may rave to the great Wall of China" (Fitzgerald 230). Then he questions of its existence: "Is there such a wall? Is it as big as Old London Wall, by Bedlam” (230)? Lamb obviously has got some information about China from somewhere, but he is eager to know more, such as the human beings living in China: "How do you like the Mandarinesses? Are you on some little footing with any of them" (Fitzgerald 238)? In the next letter, informing Manning of his new address, he goes on to invite guests from China, saying "I am now in chambers, No.4, Inner Temple Lane, where I should be happy to see you any evening. Bring any of your friends, the Mandarins, with you" (Fitzgerald 238-39). In light of the above evidence, it may well be said that China stimulates Lamb's curiosity. ${ }^{7}$

Besides curiosity and very limited knowledge of China, Lamb's imagination of this faraway country is also intertwined with his personal feelings for Manning. Lamb’s letters regarding China are mostly sent to Manning or their mutual friend, discussing Manning's trip to China. Kitson states: "throughout these letters, Lamb's register and tone remain at the level of gossip, whimsy, and often melancholy" (173). Lamb’s melancholy stems mostly from the "going away" of Manning, one of his lifelong friends. Lamb cherishes their friendship so much that, even when they are widely parted, he manages to keep

${ }^{7}$ In a certain sense it may be said that Lamb’s awareness of China was in tandem with a trend from eighteenth-century to Romantic orientalism as marked by an increase in the direct knowledge of the East. For example, as a popular type of literature, travel books about the East gained great popularity in the period, 1775-1825. The materials and interpretations in these books captured the imagination of numerous writers in England. It is clearly indicated by the continuous attention given them in contemporary magazines. See Wallace Cable Brown. Nigel Leask gives another explanation for this trend, tracing it back to its earlier origin: "The writers of the Romantic age had interests in the 'Orient' to a degree which went far beyond their Augustan and mid-eighteenth-century forebears” (see Leask 18). 
correspondence with Manning. In the letters, Lamb repeatedly mentions a man named Samuel Ball, who is Lamb’s India House acquaintance and school friend, asking "Have you met with a friend of mine, named Ball, at Canton” (Fitzgerald 230)? ${ }^{8}$ As Kitson analyses, the reason Lamb encourages Manning to seek out Ball's company might be that he thinks "it will be good to be the subject of a conversation in that part of world” (173). However, Lamb's attempt to avoid losing communication with Manning is, unfortunately, to no avail.

As a result of the huge distance in between, they could no longer keep in close touch, neither regularly meeting each other, nor sharing social information or details of private life through letters. Hence, in a letter written to Manning in 1806, Lamb complains: "You will be so sorry, that you will not think the best of me for my detail; but news is news at Canton" (Fitzgerald 227). China is naturally set in the position opposite to London. In other words, it becomes quite like Lamb’s enemy, who steals his friend and brings him away from his life. In still another letter, Lamb writes:

I understand there are dramatic exhibitions in China. One would not like to be forestalled. Do you find in all this stuff I have written anything like those feelings which one should send my old adventuring friend, that is gone to wander among Tartars and may never come again? I don't; but your going away, and all about you, is a threadbare topic. I have worn it out with thinking: it has come to me when I have been dull with any thing, till my sadness has seemed more to have come from it than to have introduced it. I want you, you don't know how much; but if I had you here in my European garret, we should but talk over such stuff as I have written - so. (Fitzgerald 229) ${ }^{9}$

In this letter, Lamb expresses an understanding of Manning's choice to China, though he does not conceal his sadness. He is filled with the fear of losing his "old adventuring friend" and of the need to have his companionship. This sadness is further intensified by the otherness of China, the nation where Manning is residing.

The otherness of China consists of various elements. The first is the huge geographical distance between Britain and China, the country that is located at "the farthest ends of the world" (Fitzgerald 230), noticeably emphasized by Lamb. The distance is embodied as “a five months' voyage," causing Lamb to fall into panic as he writes to Manning: "China! Canton! Bless

8 Manning met Ball in Canton. His first impression of Ball may be interpreted, presumably, as meaning: "Mr. Ball is a puppy"; but later Ball returned to England, at much the same time as Manning, and they remained friendly throughout their lives, visiting Italy together, in 1827-8 (see Anderson 99).

${ }^{9}$ In this letter, Lamb confuses Chinese people with the Tartars again. 
us-how it strains the imagination and make it ache!” (Fitzgerald 224). This feeling could never be dispelled, and it develops into a sense of otherness in Lamb's thoughts, as he says: "Nothing puzzles me more than time and space; and yet nothing puzzles me less, for I never think about them.... The distance you are at cuts up tenses by the root" (Fitzgerald 240-41).

On the other hand, the remoteness of the space is associated with the gulf between the two cultures. One aspect of the cultural difference is the linguistic diversity, as Lamb says: "albeit unknown to the Chinese inquirer" (Fitzgerald 256). Another lies in the religious discrepancy between the two countries. Lamb once threatens Manning that "you are gone to plant the cross of Christ among barbarous pagan anthropophagi, you'll get murdered" (Fitzgerald 223). ${ }^{10}$ Again, in a letter written on Christmas day 1815, Lamb childishly complains: "You have no turkeys; you would not desecrate the festival by offering up a withered Chinese bantam, instead of the savoury grand Norfolcian holocaust, that smokes all around my nostrils at this moment from a thousand firesides" (Fitzgerald 243). The cultural differences build up Lamb’s "European garret," which is set in contrast with an assumptive "Chinese garret." Thinking of the cultural barrier in this way, Lamb writes another letter to Manning, saying, "I sent you a parcel of books by my last, to give you some idea of European literature” (Fitzgerald 239). Lamb’s sarcasm actually indicates his intensified anxiety towards Manning's preoccupation with Chinese culture, so much so that he has to constantly remind him to look back to Europe. On a deeper level, the other represented by China is intensively diffused over a wider area, the Orient, as Lamb teases: "'Tis all about Eastern manners; it would just suit you" (Fitzgerald 233). The gap between the self and the other is as well a barrier meant to maintain Lamb's distance from the Orient.

Furthermore, as an area of consumption and production - the assemblage, demolition and reconstitution of otherness-orientalism had undergone important transformations in the Romantic period. The personal connections of Romantic writers to the Orient were strengthened, as Nigel Leask enumerates: "Coleridge, Southey, Lamb, Peacock, Moore, De Quincey and Scott all had personal and/or professional stakes in Britain's oriental empire” (19). Among them, Lamb is deeply associated with the oriental empire. As an employee of the East India Company in London for some thirty years, he is called the "Lamb of the India house” (Anderson 102). Though his life might have been deeply shaped by the East India Company, Lamb recalls the experience as one "with cursed India House work" (Fitzgerald 93), lamenting that it is like "to waste the

${ }^{10}$ According to T. H. Barrett, Manning's nominal purpose to the study of Chinese is in a search for confirmation of certain ideas concerning Greek particles, not to spread Christianity, as Lamb suggests (see Barrett 58). 
golden years of thy life- thy shining youth —in the irksome confinement of an office" ("The Superannuated Man" 193). As for what he does at work, he claims resolutely: "I scarce know what I do" (Fitzgerald 93). However, it is revealed that "his employment intimately bound up with the tea and opium trades" (Kitson 169). This working experience has left traces in his life, as Kitson mentions, "The nexus of China, consumption, commerce, and global expansion is clearly present in Lamb's writings" (171). From these words, we can see that he apparently recognizes what happened in China, and knows "how very serious the attainment of the Chinese language was to British understandings of China and its crucial purpose in commerce" (Kitson 174). Having a chance to touch the other part of the world, Lamb sharply observes the changes appeared in the world, accounting: "Empires have been overturned, crowns trodden into dust, the face of the Western world quite changed" (Fitzgerald 244). Changes in the empires were inextricably bound up with the outward expansion of the Great Britain, which took an important role in the forced participation of China in the Global consumption.

The image of China, as Lamb portrays in the essays published in London Magazine, has been widely discussed by critics. They particularly focus on Elia, the protagonist of Lamb’s series of essays. As Karen Fang mentions, “'Old China' illustrates that for Elia porcelain is unrivalled by other exotic commodities as literary subject” (822). Elia's interest in Chinese commodities is associated with England's commercial relations with China, which brings about considerable debate from a cultural consumptive perspective. Fang states that in the essay "Old China," widely acknowledged as a literary simulation of imperial commodity, Lamb "shows how second-generation romantics could attain visionary experiences through the visual pleasures of contemporary consumer culture” (827). In this way, scholars often concentrate on the commodity objects in Lamb's essays when discussing his thoughts on China, arguing the prominent porcelain symbol in "Old China" is one such example. Fang also points out that Lamb is "embracing China through porcelain-China's miniature form" and "the very noun 'china' names the commodity as a material synecdoche for its country of origin” (822). Her conclusion, “'Old China' is literary chinoserie for an age shaped by the new imperial industry” (837), again connects Lamb's discourse of China with an imperial consciousness. Indeed, thirty-six years of working at the East India Company builds Lamb as a key witness to the rise of the imperial consumptive culture of the time, but also helps construct the otherness of China through the exotic features of Chinese commodities and their potential threat to the imperial markets. 


\section{"You should have sent your Tales from Shakespeare": A Presumption of the Arrival of Tales in China}

In 1806, William Godwin, an English political philosopher, and his second wife asked Mary Lamb to make a children's book of stories from Shakespeare's plays. Charles Lamb offered to help undertake half of the work, writing all the tragic stories in the book. In a letter to Wordsworth in 1807, Lamb described his work: "I will try to abstract the load of teasing circumstances from the stories and tell you that I am answerable for Lear, Macbeth, Timon, Romeo, Hamlet, Othello, for occasionally a tail-piece or correction of grammar, for none of the cuts and all of the spelling. The rest is my Sister's" (Fitzgerald 87). Joan Coldwell analyses the reason for Lamb's involvement in the book, as "perhaps because of the nervous stain the task might impose on his sister" (81). Whatever reason caused him to start the project, Lamb admirably engaged in writing this book and had high hopes for it, as he told Wordsworth: "We think Pericles of hers the best, and Othello of mine; but I hope all have some good" (Fitzgerald 87). Actually, the Lambs' Tales is a far better work than merely having "some good." "Lamb, together with his sister," as Coldwell comments, "did pioneering work and, in this case, it has not been better editor" (14).

Notably, in the process of writing Tales, Lamb continuously shared information about this book with Manning through letters. When he began the work, he wrote to Manning, informing him of the work's details: "[Mary] is doing for Godwin's bookseller twenty of Shakespeare's plays, to be made into children's tales. Six are already done by her; to wit, the Tempest, the Winter's Tale, Midsummer Night's Dream, Much Ado about Nothing, the Two Gentlemen of Verona, and Cymbeline. The Merchant of Venice is in forwardness. I have done Othello and Macbeth, and mean to do all the tragedies" (Fitzgerald 223). Later, when he was about to complete the book in 1806, he informed Manning: "Those Tales from Shakespeare are near coming out" (Fitzgerald 229). In response, Manning paid close attention to this book. For example, when the book was first published in 1807, only the name of Charles Lamb appeared on the title page. Manning immediately wrote to Lamb, asking: "I have seen the Advertisement of your Tales from Shakespeare. Why not Mary's?" (Anderson 100).

A detail, which has largely escaped the attention of previous critics, emerges from Manning's letters to Lamb and becomes the crux of the matter in the discussion. From 1807, the year Tales was published, Manning constantly asked Lamb to send him a copy of the book during the next three years. Manning first sent out his request in 1807, when he was informed that the book was published: "You send me a copy, no doubt, by the direct fleet. How strange \& unsocial it seems to be at such a distance" (Anderson 100). However, the request was ignored by Lamb, leading Manning to angrily write to him in 
the next letter in 1808, saying: "You don't deserve a line from me-why did you not write by the Direct fleet? Why did you not send your Shakespeare's tales?" (Anderson 105). Then, from a later letter in 1809, Manning once again referred to the book, interrogating Lamb that "You should have sent your Tales from Shakespeare" (Anderson 114). Obviously, Manning's wish to have a copy of the book was not satisfied until then. In the same year Lamb wrote back to Manning, finally mentioning that he would send him some books, saying "Dear Manny, I sent you a long letter by the ships which sailed the beginning of last month, accompanied with books, \&c [...] if you have received my books, you will have enough to do to read them" (Fitzgerald 236). We are not actually told whether the Lambs' Tales was included in this shipment of books sent to China. But we can ascertain that it is only after this letter that Manning finally stopped asking for Tales. Hence, we can infer from this evidence that the Lambs' Tales was probably sent to Manning around 1809. In light of this assumption, it is possible to trace the arrival of Shakespeare in China back to the beginning of the nineteenth century, when the Lambs' Tales first reached there. This was even earlier than 1839, when the Bard's name first appeared in China in Lin Zexu's 林則徐 Sizhouzhi 四洲誌 [Geography of the Four Continents].

Moreover, though the appearance of Tales in China seemed accidental, it might be related to the topic of cultivating Chinese people. In a letter to Manning, Lamb wrote: "The Shakespeare Tales suggested the doing of it. [...] You have seen 'Beauties of Shakespeare'? so have many people that never saw any beauties in Shakespeare" (Fitzgerald 232). In the same letter, Lamb turned his attention to Chinese people, who also belonged to the group that "never saw any beauties in Shakespeare," asking "Does anyone read at Canton?” He further suggested Manning to become a president of any "similar institution" of the Westminster Library. He thought that this kind of enlightenment institution should be set up in Canton, arguing: "I think public reading-rooms the best mode of educating young men. Solitary reading is apt to give the headache" (Fitzgerald 235). It is possible to speculate that Lamb might suggest bringing Shakespeare to young men in China. In actuality, his concern in cultivating Chinese young people deeply corresponded to his initial purpose of writing Tales, wchich was designed to popularize the Bard among Lamb's contemporary youth in England, making the stories of Shakespeare's plays familiar to them.

For further investigation, I will discuss the role Manning might have played in promoting the Lambs' Tales. Though Manning had learned Chinese for years before he went to China, it was after he finally reached China that "the veil'd Mysteries of the Chinese language gradually were opening to his view" (Anderson 16). G. A. Anderson, the editor of The Letters of Thomas Manning to Charles Lamb points out that "we hear of him as being always ready to assist the translators of works from the Chinese, and as drawing up a report on the 
consumption of tea” (16) ${ }^{11}$ It corroborates a fact that Manning was competent to translate between English and Chinese. Based on this information, a piece of evidence draws my attention: in one of the letters to Lamb, Manning wrote: "I have long been working my brain to do something for you. I would not have you laugh at my interest..." (Anderson 101). Here, Manning's "interest” might be his enthusiasm in learning Chinese, for Lamb had complained of his spending too much time on pursuing the Chinese language. Kitson makes a similar statement: "Lamb comically chastises his friend for his time-consuming efforts in learning the Chinese language, while the familiar world of London and his friendships slowly but inevitably decays" (173-74). A follow-up question is what Manning meant when he stated that he wanted to do something for Lamb, as he then said: "You told me there was nothing to be done for you. I am sure that cannot be literally true" (Anderson 101). One possibility, what I will boldly assume, is that Manning might want to translate Tales (maybe parts) once he got the book from Lamb. Though it is only an assumption, and needs further documented evidence to validate, it still sheds some light on the first encounter between Shakespeare and China through the Lambs' Tales.

\section{“All China will ring of it by and by": Translating Tales in China ${ }^{12}$}

The first documented translation concerning Shakespeare in China is Xiewai qitan, which is selectively translated from the Lambs' Tales by an anonymous author in $1903 .{ }^{13}$ The book was published one year ahead of the publication of Yinbian yanyu, which gained massive success in the publishing market. Yinbian is also a translation from the Lambs' Tales, published by the Commercial Press in 1904. It was extremely popular among Chinese readers, so much so that between 1905 and 1935 it was reprinted eleven times in three different editions. The work's immense popularity corresponded to its profound influence. Cao Yu 曹禺, one of China's most important playwrights of the twentieth century, said in an interview: "One of my favorite Western playwrights is Shakespeare, and my fondness of the Master’s plays started from reading Lin Shu’s Yinbian yanyu

${ }^{11}$ Among Lamb’s two famous Elia essays on China, “Dissertation upon Roast Pig” was claimed to be based on the translation of a Chinese manuscript that was obtained from his friend M. (Manning).

12 The original context of the sentence exaggeratedly describes Lamb's imagination of the moment when his letter to Manning finally would have achieved China: "And only think how hard upon me it is that the ship is dispatched to-morrow, and my triumph cannot be ascertained till the Wednesday after; but all China will ring of it by and by" (Fitzgerald ed. 228).

${ }^{13}$ It is important to note that in 1903 three lines of Polonius in Shakespeare's Hamlet were translated into Chinese from a Japanese translation of Self-Help (see Hao 45-46). 
when I was a little boy. As soon as I was able to read in English, I was eager to get hold of a Shakespeare play, because Lin's translation of the Bard's fantasy world was so fresh in my young mind" (see Li Ruru's personal interview with Cao, Li 16) ${ }^{14}$ Other than Cao, many contemporary Chinese authors expressed how they were attracted to and influenced by Yinbian. Big names such as Lu Xun 魯迅, Hu Shih 胡適, Zhu Ziqing 朱自清, and Qian Zhongshu 錢鍾書 were known to have discussed this book. Yinbian served to arouse their interest in reading Western literatures. Even when they had a chance to obtain Shakespeare's original texts, Lin and Wei's collaborative translation of the Lambs' Tales was still appealing to them. The widely circulated translation of Tales exerted enormous influence on Chinese Shakespeare reception. It helped to spread the name of the Master throughout the country, and even made a significant impact on the modernization of Chinese literature, culture, and society.

With the expansion of the notion of translation process, the selection of the source text is included into discussion. As the first two Chinese receptions concerning Shakespeare, Xiewai qitan and Yinbian yanyu are both translated from the Lambs' Tales, a crucial question arises: why the Lambs' Tales rather than the Bard's original texts? To answer this question, an important point to note is that the authors of the source texts, as Hanne Jansen and Anne Wegener argue, "can also have 'a finger in the pie' if he or she engages with the translator's work" (20). Though there is no possibility for Lambs to actually work with the Chinese translators, as the year 1903 when Lin and Wei began their work on Yinbian was decades after the Lambs' deaths. They did make efforts on this translation activity. In what follows, I will argue how Lambs influenced Chinese translators' choice in two aspects.

First, the translators' choice was made in the consideration of the marketability. With the development of the publishing market in early modern China, the market was of such importance that it greatly influenced the choice of texts selected for translation. To ensure the translation would be saleable, the source text must be popular in its original culture. The warm welcome Tales received in the West undoubtedly laid the foundation for the translators' choice. At the beginning of starting Tales, Lamb wrote to Manning: "I think it will be popular among the little people, besides money" (Fitzgerald 223). The success of Tales proved to be much greater than merely "popular among the little people." It was the first book concerning the works of Shakespeare, as A. H. Thompson evaluates, "appealing to a general audience” (Coldwell 15). The success of Tales in the Western culture was pertinent to the way in which Lambs organized and presented Shakespeare's stories. Their fairy-tale style renditions, as Thomas

${ }^{14}$ Enthroned as China's Shakespeare, Cao is one of the founders and early advocates of Chinese modern drama. 
Talfourd argues, established a fit counterpoise, not only bringing the outlines of the Bard's plots "within the apprehension of children," but also preserving his language "wherever it was possible to retain it" (66). In a similar manner, Coldwell comments, "The Tales from Shakespeare are clear and forceful narrative condensations of the plays, which do not talk down to their young audience but show, in their skilful paraphrasing, a firm mastery of Shakespeare's complex language and thoughts” (14). In this light, the Lambs' Tales, the adaptation for British children and women, was widely read in Western countries outside Britain, and multiple editions of the work have been published, including many translations into foreign languages.

When choosing a text to translate, another essential point for Chinese translators at the turn of the twentieth century to consider was whether the text had the potential to be popular among the target audience. Accordingly, translators laid much emphasis on the reading level of average Chinese readers. They had to, as Wong Wang-chi argues, "take the tastes of the readers into serious consideration" (23). In the case of Yinbian, their target readers were the group of people, as Lamb earlier mentioned, who never saw any beauties in the Bard before. Coincidently, the target readers of Tales were also, as Alexander Huang mentions, "children and women who would otherwise not meet with Shakespeare's work" (60). On the other side, the Lambs' Tales, as Andrew Shoenbaum argues, was not only "used to bring Shakespeare to a wider audience" who did not know Shakespeare before, but also used "as a text of higher education for those who could afford that education" (102). Shoenbaum then concludes: "They served this function in China as well" (102). Indeed, the contemporary readers of Yinbian also belonged to the elite group with higher education in China. Thus, though the target readers of Tales were changed from the children and women in the West to the male elites in China, they still have a lot in common.

Other than the similarities of the target audience, the Lambs' writing style and genre choice also played an important role in Chinese translators' decision-making process. Contemporary Chinese translators were, as Wong addresses, "very cautious not to import too alien a form to confront the readers" (34). As André Lefevere argues, if the translated work "does not conform to the demands of the genre that dominates the target culture, its reception is likely to be rendered more difficult" (92). At the beginning of the twentieth century, it was difficult for Chinese audience to understand Shakespeare's dramatic form rooted in the Western cultural context, which was largely different from the concept of opera in China. Therefore, Chinese translators at that time found that rather than introducing a new genre, Tales might be easier for their readers to accept when they came into contact with Shakespeare for the first time. Moreover, as Walter Benjamin argues, "what is selected is usually what could also be written in the translator's own language” (250-51). The Lambs’ prose, 
with "simple, unambiguous, and definitive narratives" (Marovitz 475), seemed more possible to be translated into Chinese than the Bard's original. Ultimately, the translators' choice turned out to be a wise decision, particularly as evidenced by the success of Yinbian contributing to the spread of Tales in China.

\section{Conclusion}

In discussing Lamb’s “Old China," Kitson says metaphorically: "Like the texts of Chinese translations, the cup is thus a product of global exchange and commerce" (171). Translating the Lambs' Tales into Chinese is also a case of global exchange. At the turn of the twentieth century, China was forced into the international world and inevitably drawn into the globalization. It was a time full of major intellectual and social shifts in China. Needless to say, the field of literature also experienced an unprecedented influx of new concepts, formulations, approaches, and practices. In the given circumstances, Yinbian yanyu opened a window to a world's classic, such as Shakespeare, and thus opened the door to the massive importation of Western literature.

The reason why the Lambs' Tales was chosen as the source text to translate instead of Shakespeare's original works should be considered from both angles of the addresser and the receptor respectively, for the cultural encounters are possibly made by efforts from both sides. As I have argued, the Lambs' Tales might have had a chance to reach China in the beginning of the nineteenth century through the Sinologist Thomas Manning. One century later, Tales exerted a great impact on Chinese literary history with the wide circulation of its translation, Yinbian yanyu. In fact, nothing is coincidental in the history of cultural reception. Tracing back to the origins of the first encounter between Shakespeare's tales and China may throw considerable light on the history of Chinese Shakespeare reception.

Admittedly, Charles Lamb did not conceal his ambition for gaining honour and leaving a mark on literary history. In one letter to Manning he candidly expressed: "we shall die in our beds with a fair literary reputation" (Fitzgerald 223). Tales, undoubtedly, contributes to Lamb's reputation, as Thompson comments: "It is fortunate that the work of popularizing Shakespeare was done upon so solid a foundation of knowledge and poetic sensitivity as Lamb possessed" (Coldwell 15). The reputation Lamb was pursuing goes beyond the Western world. Fang also quotes Lamb's wish to have his name "talked of in China," saying that "such a wish illustrates how China figured for Lamb as an index of fame, as well as how imperial careers such as Manning's might achieve such fame” (827). Indeed, Lamb once said to Manning that he wished to have his name joined with the name of Manning, who was regarded as "possibly one of the greatest China scholars of the age" (Kitson 170). Lamb's 
success with Tales and its translations of in Chinese has finally left a legacy on the literary histories of both the West and China. ${ }^{15}$

Through the spread of Tales among Chinese people, the beauties of the Bard have been brought into the trend of globalization and also involved China in the establishment of the global Shakespeare. As Lefevere claims, "rewritings seem to be a vital factor in determining whether a writing does or does not secure the label of greatness" (138). The success of Tales, a rewriting of Shakespeare's plays, is undoubtedly a well-known case in the world literary history.

\section{WORKS CITED}

Anderson, G. A., ed. The Letters of Thomas Manning to Charles Lamb. London: Martin Secker, 1925.

Ballaster, Rosalind. Fabulous Orients: Fictions of the East in England 1662-1985. Oxford: Oxford UP, 2005.

Barrett, T. H. Singular Listlessness: A Short History of Chinese Books and British Scholars. London: Wellsweep, 1989.

Benjamin, Walter. "Translation - For and Against," trans. Edmund Jephcott. Walter Benjamin: Selected Writings, vol. 3. Ed. Howard Eiland and Michael W. Jennings. Cambridge, MA: The Belknap Press of Harvard UP, 2002. 249-52.

Brown, Wallace Cable. "The Popularity of English Travel Books about the Near East, 1775-1825.” Philological Quarterly 15 (1936): 70-80.

Coldwell, Joan, ed. Charles Lamb on Shakespeare. Gerrards Cross: Colin Smythe, 1978.

Fang, Karen. "Empire, Coleridge, and Charles Lamb’s Consumer Imagination.” Studies in English Literature, 1500-1900 43.4 (2003): 815-43.

Fitzgerald, Percy, ed. The Life, Letters, and Writings of Charles Lamb, vol. 2. New York: For Libraries Press, 1971.

Guarde-Paz, César. "A Translator in the Shadows of Early Republican China: Lin Shu's Position in Modern Chinese Literature: An Overview.” Monumenta Serica: Journal of Oriental Studies 63.1 (2015): 172-92.

Hao, Tianhu. "John Milton and the Theory of Evolution, Self-Help, and the Formation of Modern Education in Early-20th-Century China." Fudan Forum on Foreign Languages and Literature, vol. autumn (2018): 42-48.

Huang, Alexa C.Y. "Lin Shu, Invisible Translation, and Politics." Perspectives 14 (2006): 55-65.

Jansen, Hanne, and Anne Wegener. "Multiple Translatorship." Authorial and Editorial Voices in Translation 1: Collaborative Relationships between Authors, Translators and Performers. Ed. Hanne Jansen and Anne Wegener. Montréal: Éditions québécoises de l'oeuvre, 2013. 1-39.

${ }^{15}$ Lamb claimed in his letter that Manning's name affected him "like a legacy" (Fitzgerald 224). 
Kitson, Peter J. Forging Romantic China: Sino-British Cultural Exchange 1760-1840. Cambridge: Cambridge UP, 2013.

Lamb, Charles. “The Superannuated Man.” The Works of Charles and Mary Lamb, vol. 2. Ed. E. V. Lucas. London: Methuen, 1903.193-99.

Lamb, Charles and Mary. Tales from Shakespeare. Shanghai: The Commercial Press, 1922.

Leask, Nigel. British Romantic Writers and the East. Cambridge: Cambridge UP, 1992.

Lefevere, André. Translating Literature: Practice and Theory in a Comparative Literature Context. New York: The Modern Language Association of America, 1992.

Li, Ruru. Shashibiya: Staging Shakespeare in China. Hong Kong: Hong Kong UP, 2003.

Lin, Shu 林紓 and Wei Yi 魏易, trans. Yinbian yanyu 吟邊燕語 [An English Poet Reciting from Afar]. Shanghai: The Commercial Press, 1904. Rpt. 1981.

Lucas, E. V., ed. The Works of Charles and Mary Lamb, vol. 6. London: Methuen and Co., 1903-05.

Radcliffe, David Hill, ed. The Works of Charles and Mary Lamb. Lord Byron and His Times. N.p., Jan. 2012. Web. 14 June 2016.

Shoenbaum, Andrew. “The 'Hamlet Complex' in China, 1903-1936.” Shakespeare and Asia. Ed. Douglas A. Brooks. Lewiston, NY: The Edwin Mellen Press, 2010. 101-23.

Talfourd, Thomas. “'Mr. H.’- Temple Lane. - The 'Quarterly Review’ Attack.” The Life, Letters, and Writings of Charles Lamb, vol. 2. Ed. Percy Fitzgerald. New York: For Libraries Press, 1971. 62-73.

Tu, Hsin-hsin. “Literature, Translation, and the Critics: On Prémare’s Translation of Le Petit Orphelin de la Maison de Tchao.” Compilation and Translation Review 3.2 (2010): 61-99.

Wong, Wang-chi. "An Act of Violence: Translation of Western Fiction in the Late Qing and Early Republican Period.” The Literary Field of Twentieth-Century China. Ed. Michel Hockx. Richmond, Surrey: Curzon Press, 1999. 21-39. 